\title{
Underwriting and Investment Risks in the Property-Liability Insurance Industry: Evidence Prior to the 9-11 Event
}

\author{
Joe Zou \\ Department of Economics and Finance \\ City University of Hong Kong \\ 83 Tat Chee Avenue, Kowloon Tong, Kowloon, \\ Hong Kong, China \\ Email: hongzou@cityu.edu.hk \\ Tel: (852) 34427880 \\ Fax: (852) 34428842 \\ Min-Ming Wen \\ Department of Quantitative Finance \\ National Tsing-Hua University, Taiwan \\ 100 Kung-Fu Road Sec 2, Hsin-Chu 300, Taiwan \\ Email: minmingwen@yahoo.com \\ Tel : (886) 2-2234-6648 \\ Charles Chuanhou Yang \\ School of Finance, Insurance, and Economics \\ Florida Atlantic University \\ 777 Glades Road, Boca Raton, FL 33431 \\ Email: cyang1@,fau.edu \\ Tel: (1) 561-297-4181 \\ Mulong Wang \\ Grange Mutual Insurance, USA. \\ Email: wangmulong@gmail.com
}

We thank the helpful comments from Cheng-Few Lew (the editor), two anonymous referees and suggestions offered by Steve Diacon, Yiyi Li, Grace Pan, Yong Tang, Gang Wei and Tong Yu. Research assistance of Grace Pan is appreciated. 


\title{
Underwriting and Investment Risks in the Property-Liability Insurance Industry: Evidence Prior to the 9-11 Event
}

\begin{abstract}
Underwriting and investment are two important and related business activities of insurance companies. However, studies on the interrelation between underwriting and investment risks of Property-Liability (P-L) insurance companies are sparse in the literature. Using a sample of U.S. P-L insurers, this article conducts an empirical investigation of how these two risks are associated with each other in the 1994-2000 period (before the September $11^{\text {th }}$ terrorist attack in 2001). Our results, robust to various estimations, suggest that there is no significant relationship between the underwriting and investment risks among our sample firms. Such results based on pre 9-11 event period provide some support for the conjecture of Achleitner et al. (2002) that many insurance companies may have failed to take an integrated approach to risk management and so suffered a heavy loss due to dual exposures in both underwriting and investment in the 911 event. In the aftermath of the recent global financial crisis, risk taking and risk management of financial institutions have received more attention and increasing scrutiny. We believe the current paper provides some useful insights in this vein.
\end{abstract}

Keywords: Underwriting risk; Investment risk; Risk-taking; P-L insurers

JEL Code: G11, G22, G32 


\section{Underwriting and Investment Risks in the Property-Liability Insurance Industry: Evidence Prior to the 9-11 Event}

\section{Introduction}

A firm's risk-taking behavior has aroused numerous research interests because it concerns the financial interests of various corporate stakeholders. This is particularly germane in financial industries where the protection of depositors and/or policyholders is always of the paramount concern. ${ }^{1}$ In this article, we investigate the interrelation between underwriting and investment risks of property-liability insurers' (P-L insurers). Though underwriting and investment are the two primary and related business activities of an insurer (Adams, 1999; Adams and Buckle, 2003), the interrelation between underwriting and investment risks for P-L insurers has not been rigorously examined in the literature. ${ }^{2}$

To our best knowledge, Hammond, Melander and Shilling (1976) is the only study that provides a direct test of the relation between underwriting and investment risks in the P-L insurance industry. They regress underwriting risk (measured by the ratio of net premiums to equity) on investment risks (proxied by standard deviation of investment returns to invested assets or the proportion of equity investment) of 26 P-L insurers for the period 1952-1967 and document a negative relation. They conclude that P-L insurance managers may choose an overall

\footnotetext{
${ }^{1}$ Prior studies on the risk-taking behavior of financial institutions (e.g., banks and insurance companies) mainly go along three lines. First, one line focuses on the relation between risk-taking behavior and ownership structures of financial institutions. Studies (e.g., Saunders, Strock and Travlos, 1990; Downs and Sommer, 1999; Chen, Steiner and White, 2001) have examined the effect of managerial ownership on risk taking. Lamm-Tennant and Starks (1993) compare the underwriting risk of stock and mutual P-L insurers and report that stock insurers tend to exhibit a higher underwriting risk than do mutual firms. A second line examines whether franchise value of financial institutions can mitigate excessive risk-taking (e.g., Keeley, 1990; Staking and Babbel, 1995; Demestz, Saidenberg and Strahan, 1996; Saunders and Wilson, 2001). A third line investigates the relation between capital and overall risk-profile of insurers (e.g., Cummins and Sommer, 1996; Baranoff and Sager, 2002).

${ }^{2}$ Prior insurance-related studies use various terminologies to describe insurance firms' major risks - for example, assets/investment risks and liabilities/product/underwriting risks. In the current study, we adopt the terms of underwriting and investment risks.
} 
desired level of risk by trading off underwriting risk against investment risk. However, their univariate analysis fails to control for any relevant factors of underwriting risk and their underwriting risk measure is also crude (and similar to the Kenney ratio and thus essentially a measure of underwriting capacity). Our study bridges this gap by examining not only the effects of investment risk on underwriting risk, but also the effects of underwriting risk on investment risk by controlling the exogenous factors.

Our study is also motivated by the article by Achleitner, Biebel and Wichels (2002) in which they report that some big insurers (e.g., Allianz ${ }^{3}$ ) suffered a heavy loss because of a dual exposure to aviation industry risk (i.e., on both the underwriting and investment sides) caused by the September $11^{\text {th }}$ terrorist attack (hereafter the "9-11 event"). They conjecture that the insurance industry may have neglected or underestimated the correlation between underwriting and investment risks and may have largely taken a silo approach in managing the risk of underwriting and investment activities. We conduct an analysis specifically based on a sample period prior to the 9-11 event to exclude the confounding effects from that event year and the post-event effects. ${ }^{4}$ Therefore, we believe that our rigorous examination can shed light on the relationship between insurers' underwriting and investment risks. Thus the evidence on the linkage between insurers' underwriting and investment risks should be of significant interest to regulators, investors, policyholders and insurance managers. Especially when enterprise risk management becomes more prevalent in insurance industry, an integrated risk management on both underwriting and investment risks is even more important than ever.

\footnotetext{
${ }^{3}$ For example, Achleitner et al. (2002) report that the Allianz Group suffered a loss of more than 4 billion Euros in its investments in the initial several days following the attack on the WTC and incurred liabilities of 1.5 billion Euros while the significant underwriting loss was expected.

${ }^{4}$ Due to data limitation, we leave the effect of the $9-11$ event on the relation between underwriting and investment risks as an interesting question for future research.
} 
Our study is also related to two prior studies. Cummins and Sommer (1996) treat the underwriting and investment activities of (stock) P-L insurance firms as a portfolio of two funds and calculate an aggregate risk measure by taking account of the covariance between the underwriting and investment returns. They report a positive relationship between stock P-L insurers' capital and the aggregate risk proxy. Our investigation of the interrelation between the two core risks complements their work and contributes to the understanding of the dynamics between underwriting and investment risks.

Baranoff and Sager (2002) examine the capital-risk relation in the life insurance industry and their simultaneous equations include two specifications of underwriting (proxied by the proportion of health insurance business) and investment risks (a regulatory-based asset risk measure). Their results suggest a positive two-way linkage between the underwriting and investment risks for life insurers despite no interpretation offered in their paper. Given the well recognized significant differences between life and P-L insurance businesses ${ }^{5}$, it is necessary to examine the linkage between underwriting and investment risks separately for P-L insurers.

Another contribution of our study is that we use a large sample of both stock and mutual insurance firms (581 firms), while prior studies typically use data on stock insurers. We believe that the inclusion of mutual firms is important given that in the insurance industry (e.g., of the U.S.), a large proportion of insurance firms is represented by mutual firms for which there is no

\footnotetext{
${ }^{5}$ P-L and life insurers tend to differ in their earnings mix (i.e., with P-L insurers' profit relying more on investment income) and the investment of P-L tends to be riskier. For example, Hammond and Shilling (1978) and Fairley (1979) report that many P-L insurers have zero or negative underwriting profit and rely on investment income for profit. In contrast, Boose (1993) notes that only about one-third of life insurers' profit is typically derived from investment income. In addition, while life insurance's underwriting function is reasonably predictable (thank to the use of mortality table), the occurrence of P-L insurance claims is largely uncertain and stochastic.
} 
market-based data available. As such, our study provides new insights into the risk-taking behavior of both types of P-L insurance firms.

Following a target expected return that consists of underwriting and investment returns (Fairley, 1979), insurers are likely to control their overall insolvency risk by simultaneously adjusting their underwriting and investment risks. In the current study, we put forth two possible linkages between the underwriting and investment risks of P-L insurers - namely, the trade-off and co-movement hypothesis, respectively. The trade-off hypothesis posits that P-L insurers trade off underwriting (investment) risk against investment (underwriting) risk when their total risk level is approaching the maximum tolerant level. In contrast, the co-movement hypothesis is based upon two rationales. First, in case where the total risk level is distant from the maximum tolerant level (e.g., we term this as "having extra risk capacity" hereafter), insurers may simultaneously increase both underwriting and investment risks. In addition, some catastrophes may concomitantly cause shocks to P-L insurers' underwriting and investment sides, thereby potentially introducing a positive relation between underwriting and investment risks (Achleitner et al., 2002). Second, a high (low) investment risk is likely to result in a more (less) volatile surplus and underwriting capacity, which can then increase (decrease) the fluctuations in insurance premium rates and underwriting profit. However, we believe these two hypotheses are not mutually exclusive and both could contribute to the relation between a P-L insurer's underwriting and investment risks.

Measuring underwriting risk as the combined ratio and investment risk as the proportion of investments in common stocks, we find no significant support for either of the arguments. Our result is thus different from the finding that insurers tend to trade off underwriting (investment) 
risk against investment (underwriting) risk reported in Hammond et al. (1976). Our results that are robust to various estimations, however, provide some support for Achleitner et al.'s (2002) conjecture that the insurance industry may have overlooked the correlation between underwriting and investment risks and largely managed investment in isolation from underwriting. This silo approach can then lead to the assumption of excessive risk relating to the same source (e.g., aviation industry risk) by many P-L insurers. Our study serves as the first systematic investigation of the interrelations between P-L insurers' underwriting and investment risks and lays a ground for future work, especially those examining how the 9-11 event affects such interrelations afterwards. In the aftermath of the recent global financial crisis, risk taking and risk management of financial institutions have received more attention and increasing scrutiny. We believe the current paper provides some useful insights in this vein.

The rest of this paper is organized as follows. Section 2 discusses the linkage between the underwriting risk and investment risk of P-L insurers. Section 3 introduces the empirical models and variable measurement. Section 4 describes our sample and Section 5 presents the results. The paper is concluded in Section 6.

\section{Hypotheses development: the linkage between underwriting and investment risks}

While there are other risks (e.g., credit risk) facing insurers, we only focus on underwriting risk and investment risk in the current study because their linkage represents an important, but under-researched area. Baranoff and Sager (2002) using life insurers as an example also opine that the management of the underwriting and investment risks is the major aspect of an insurer's operation. Traditionally, underwriting is regarded as the primary activity in 
which an insurer has core competence. In underwriting, insurers take on risks in exchange for premiums. The difference between earned premiums and the sum of claims and expenses represents insurers' underwriting profit. Underwriting risk arises when actual insurance claims and expenses incurred deviate from the expected values that determine the premium level, thereby leading to the fluctuation of underwriting profit. On the other hand, insurers need to set up various kinds of reserves (e.g., unearned premium and loss reserves) to fulfill future policy liabilities. The time difference between receiving premiums and paying claims enables insurers to invest most of the premiums together with their surplus into various assets (e.g., bonds and stocks) whose risk may also affect insurers' underwriting activities. Several authors (e.g., Hammond et al., 1976; Hammond and Shilling, 1978; Moridaira, Urrutia and Witt, 1992) argue that investment return is the most important component of P-L insurers' profit because the underwriting profit of P-L insurers are often negative. Hoyt and Trieschmann (1991) also report that P-L insurers tend to invest a greater share of their assets in stocks than do their life counterparts. While such a heavier investment bet on stock market can bring a higher return for P-L insurers, it also means a higher risk borne by P-L insurers in investment.

As suggested by Fairley (1979), expected earnings to be realized at the end of a policy year consist of the underwriting profit margin and investment returns. Their relation can be formulated as

$$
\overline{r_{E}}=\overline{r_{A}}(k s+1)+\bar{p} s
$$

where $\overline{r_{E}}=$ expected return on equity ${ }^{6}$

\footnotetext{
${ }^{6}$ Empirical study by Lee and Cummins (1998) shows that the arbitrage pricing theory (APT) and Wei's unified CAPM/APT (1988) models perform better than the CAPM in estimating the cost of equity capital for the PC insurers.
} 
$\overline{r_{A}}=$ expected investment yield

$k=$ average amount of investable funds created by the cash flow per dollar of annual premium

$s=$ premium-to-capital ratio

$\bar{p}=$ underwriting margin

Equation (1) specifically indicates that P-L insurers are facing a dual risk exposure to two core risks, namely, underwriting and investment risks, which simultaneously affect insurers' insolvency risk and thereby their corporate value. In order to achieve the target level of expected returns, P-L insurers are likely to set a target overall risk level to maximize their firm value. Based on equation (1), the adjustment process of determining the target risk level relies on the dynamic adjustment processes of underwriting and investment risks. Indeed, Hammond et al. (1976) and Hammond and Shilling (1978) argue that P-L insurers' underwriting and investment risks are not independent and insurance managers may control the overall insolvency risk by trading off one core risk against the other.

Insurers may adjust investment risk according to their underwriting risk. This is because the combination of business-line underwritten by an insurer affects the composition and liquidity of its investment portfolio under an asset-liability duration matching strategy. For example, insurers underwriting highly volatile business lines may require a high degree of investment liquidity and a low level of investment volatility (e.g., via implementing a more conservative investment policy) in order to meet future policy liabilities. It may be desirable for insurers to achieve their target overall level of risk by adjusting investment risk according to underwriting risk (Hammond et al., 1976; Achleitner et al., 2002) because of two reasons. One, regulations on 
rate-setting in the P-L insurance industry are more stringent compared to those on investments in the U.S. and thus insurers could be constrained in promptly adjusting their underwriting risk through changing premium rates. On the other hand, when capital is inadequate relative to liabilities, P-L insurers in principle can choose to scale down their liability side (i.e., underwriting less business, switching to less risky businesses or changing underwriting criteria). However, this is an inflexible and potentially costly solution given its adverse impacts on customers and potential damage to long-term client relationships (e.g., see Lee and Forbes, 1982; Harrington and Niehaus, 2002).

The level of investment risk may in turn induce managers to modify its underwriting policy accordingly in order to keep total risk in check. For instance, a P-L insurer with a high investment risk but find it costly (e.g., due to market imperfections) and/or difficult to adjust (e.g., at the time of a severe market downturn) may have to adopt a more stringent underwriting criteria in order to limit the total risk. Therefore, the above reasoning suggests a trade-off hypothesis as follows:

H1: Other things being equal, there is likely a negative relation between a $P$-L insurer's underwriting risk and investment risk.

Second, as P-L insurers tend to rely heavily on investment income as the profit source (Hammond and Shilling, 1978; Hoyt and Trieschmann, 1991), a high investment risk is likely to result in a more volatile surplus and underwriting capacity. As a result, it can consequently increase (decrease) the fluctuation in insurance rates and thereby the volatility of underwriting profit if internally retained earnings is an important source of P-L insurers' capital. This is 
possible as it is a common practice for regulators and insurers to restrict underwriting capacity up to certain multiples of surplus (Smith, 2001). ${ }^{7}$ This reasoning suggests a positive correlation between a P-L insurer's underwriting and investment risks. We thus formulate an alterative hypothesis (i.e., the co-movement hypothesis) on the linkage between the underwriting and investment risks of a P-L insurer. The co-movement is reinforced if an insurer fails to trade off underwriting (investment) risk against investment (underwriting) risk and is subject to dual exposures to the same source of risks on both underwriting and investment. If so, a catastrophic event can trigger the simultaneous loss in both aspects (Achleitner et al., 2002). ${ }^{8}$ Correspondingly, we develop the alternative hypothesis as follows:

H2: Other things being equal, there is likely a positive relation between a P-L insurer's underwriting risk and investment risk.

The relation between insurers' underwriting and investment risks may vary according to insurers' overall risk capacity that can be measured by the capital level of an insurer given its underwriting liabilities. For example, when an insurer's overall risk is still low and has extra capacity to take more risk, it may simultaneously increase both underwriting and investment risks in order to achieve an optimal level of overall risk. In contrast, if an insurer is approaching the regulatory limit in capital level, it may choose to trade off one risk against the other. Indeed, Cummins and Sommer (1996, p. 1071) also argue that “... adequately capitalized insurers should

\footnotetext{
${ }^{7}$ For example, the famous Kenney rule argues that the ratio of premiums to surplus for a P-L insurer should not exceed 2. In recent years, there is a declining trend in Kenney ratio in the U.S. P-L industry probably reflecting that insurers leave more financial slack for catastrophes (Cummins and Doherty, 2002). For example, Smith (2001) reports that over the period 1994-1999, the industry average for U.S. P-L insurers was in the range of 0.84-1.3. While the mean Kenney ratio of our sample is 1.12 .

${ }^{8}$ For example, in the September $11^{\text {th }}$ attack of the World Trade Center (WTC), if an insurer provided coverage to the WTC, but also held a lot of aviation and insurance shares, both its underwriting and investment losses can be substantial.
} 
be permitted to operate without restrictions on their asset and liability portfolio choices, such as stronger rules to control investment risk." This leads to our third hypothesis:

H3: Other things being equal, the relation between a P-L insurer's underwriting risk and investment risk is likely to vary according to an insurer's overall risk capacity.

It should be pointed out that $\mathrm{H} 1$ and $\mathrm{H} 2$ may not be mutually exclusive; instead, both mechanisms could be at work and contribute to the relation between a P-L insurer's underwriting and investment risks. The observed result from our tests may only reflect the dominating effect. Moreover, $\mathrm{H} 3$ serves to investigate the relations between the two core risks conditional on the insurers' risk capacity (measured by the level of Kenney ratio).

\section{Empirical models and variables}

\subsection{Models}

Following Cummins and Sommer (1996), Baranoff and Sager (2002), we adopt a system of simultaneous equations incorporating partial adjustment to examine the risk-taking behaviors of insurers. Incorporating partial adjustment is necessary because adjustments in underwriting and investment risks may not be completed within one accounting period due to market imperfections, information asymmetries and/or delays in claims handling.

Changes in the underwriting (investment) risk of a P-L insurer can be written as:

$$
\begin{aligned}
& \Delta U R_{i, t}=\Delta U R_{i, t}{ }^{D}+\varepsilon_{i, t} \\
& \Delta I R_{i, t}=\Delta I R_{i, t}{ }^{D}+v_{i, t}
\end{aligned}
$$


where $\Delta U R_{i, t}\left(\Delta I R_{i, t}\right)$ is the change in underwriting (investment) risk of insurer $i$ from time $t-1$ to $t$ and $\Delta U R_{i, t}{ }^{D}\left(\Delta I R_{i, t}{ }^{D}\right)$ is the endogenously determined underwriting (investment) risk adjustment from $t-1$ to $t$. In the partial adjustment model, variations in current underwriting (investment) risk are assumed to be proportional to the difference between the insurer's current period expectations of underwriting (investment) risk and their actual amounts at the end of the previous year, i.e.,

$$
\begin{aligned}
\Delta U R_{i, t} & =\gamma_{1}\left[U R_{i, t}{ }^{*}-U R_{i, t-1}\right]+\varepsilon_{i, t} \\
\Delta I R_{i, t} & =\gamma_{2}\left[I R_{i, t}{ }^{*}-I R_{i, t-1}\right]+v_{i, t}
\end{aligned}
$$

where $U R_{i, t}{ }^{*}\left(I R_{i, t}{ }^{*}\right)$ is insurer $i$ 's expected level of underwriting (investment) risk at time $t$ and $\gamma_{1}$ and $\gamma_{2}$ are adjustment coefficients. To complete the model, one can determine the target underwriting (investment) risk of firm $i$ from equations (6) and (7):

$$
\begin{gathered}
U R_{i, t}{ }^{*}=a_{0}+a_{1} I R_{i, t}+\sum_{j=2}^{k} a_{j} X_{i, j}+\mu_{i, t} \\
I R_{i, t}{ }^{*}=b_{0}+b_{1} U R_{i, t}+\sum_{j=2}^{k} b_{j} X_{i, j}+\Phi_{i, t}
\end{gathered}
$$

$X_{j}$ is an array of control variables of underwriting and investment risks (to be discussed in Section 3.3). Substituting equations (6) and (7) into equations (4) and (5), respectively, gives the following risk equations to be estimated:

$$
\begin{aligned}
& U R_{i, t}=\alpha_{1}+\beta_{0} U R_{i, t-1}+\beta_{1} I R_{i, t}+\sum_{j=2}^{k} \beta_{j} X_{i, j}+\xi_{i, t} \\
& I R_{i, t}=\alpha_{2}+\delta_{0} I R_{i, t-1}+\delta_{l} U R_{i, t}+\sum_{j=2}^{k} \delta_{j} X_{i, j}+\omega_{i, t}
\end{aligned}
$$




$$
\begin{aligned}
& \text { In equation (8), } \alpha_{1}=\gamma_{1} a_{0}, \beta_{0}=\left(1-\gamma_{1}\right), \beta_{j}=\gamma_{1} a_{j}(j=1 \text { to } \mathrm{k}) \text {, and } \xi_{i, t}=\gamma_{1} \mu_{i, t}+\varepsilon_{i, t} \\
& \text { In equation (9), } \alpha_{2}=\gamma_{2} b_{0}, \delta_{0}=\left(1-\gamma_{2}\right), \delta_{j}=\gamma_{2} b_{j}\left(j=1 \text { to k), and } \omega_{i, t}=\gamma_{2} \Phi_{i, t}+v_{i, t} . \quad \xi_{i, t}\right.
\end{aligned}
$$

and $\omega_{i, t}$ are error terms in the model.

\subsection{Measurement of underwriting and investment risks}

Investment risk $(I R)$ is measured by the amount of investment in common stocks scaled by the firm's cash and other investable funds, which has been used in several prior studies (e.g., Harrington and Nelson, 1986; Pottier and Sommer, 1999). ${ }^{9}$ In terms of underwriting risk (UR), we use combined ratio defined as the sum of loss ratio and expense ratio as a measure of underwriting risk in this study. A higher combined ratio implies a higher underwriting risk. This $U R$ measure captures underwriting expenses, which are not taken into consideration in Adams and Buckle (2003) that use loss ratio as a measure of underwriting risk. Lamm-Tennant and Starks (1993) measure underwriting risk $(U R)$ as the standard deviation of a firm's loss ratios over a five-year time period in comparing the underwriting risk of stock and mutual insurers. This measure has little annual variations and does not correspond to the measurement period of investment risk, and it is therefore deemed inappropriate for our study, as we intend to examine the interactions between insurers' underwriting and investment risks on an annual basis.

\subsection{Control variables}

\footnotetext{
${ }^{9} \mathrm{We}$ do not have access to the details of the investment mix of insurers and by-class return data and hence cannot use a measure reflecting the financial market risk of different asset classes. Nevertheless, in Section 5.3, we also test the sensitivity of our results using an alternative proxy of investment risk that is defined as the proportion of investment in common stocks, preferred stocks, and long-term low-grade bonds (i.e., class-3 to class- 6 bonds with a maturity over 5 years).
} 
We control for the following exogenous factors that may affect an insurer's underwriting/investment risks. Table 1 provides detailed definitions of these variables. Below we briefly discuss the effects of these variables on an insurer's underwriting/investment risks.

Firm size and Age: As in Cummins and Sommer (1996) and Baranoff and Sager (2002), firm size is included to control for the difference in risk, capital and growth opportunities among different-sized insurers. Hardwick (1997) also argues that large insurers are likely to perform better and so may have higher risk capacity than small insurers because of economies of scale. Age is also included to provide a further control for cross-sectional differences in growth opportunities and the expertise in underwriting and investment. On the one hand, large and mature firms may have less growth opportunities, more experience, and/or more capital and thereby being less risky (Smith and Watts, 1992); on the other hand, such firms may have more capital and hence a stronger ability to bear a higher risk (Cummins and Sommer, 1996; Baranoff and Sager, 2002). Therefore, the literature does not provide an unambiguous prediction of the effects of size and age on insurers' risks (including both underwriting and investment risks).

Capital ratio: According to the risk-based capital regulation in the U.S., an insurer should have a capital level commensurate with its risk level. This suggests that an insurer should consider its availability of capital and surplus in deciding on its underwriting and investment risks. Indeed, Cummins and Sommer (1996) report a positive relation between a P-L insurer's capital and an aggregate risk proxy reflecting both underwriting and investment risks. Following prior studies (e.g., Cummins and Sommer 1996; Colquitt, Sommer and Godwin, 1999), we define a firm's capital ratio as the ratio of total surplus to total book value of assets. We expect the coefficient of capital ratio to be a positive sign in both underwriting and 
investment risk equations. In order to mitigate the potential endogeneity between underwriting/investment risk and capital ratio, we lag capital ratio by one period.

Business-line mix:

P-L insurers with a high level of business concentration tend to have a higher level of underwriting risk than firms with diversified sources of premium income. Following Mayers and Smith (1994), we use a business-line Herfindahl index as an indicator of business-line concentration. The Herfindahl index is calculated as $\mathrm{HI}=\sum_{\mathrm{L}=1}^{\mathrm{n}} \mathrm{S}_{\mathrm{L}}^{2}$, where $\mathrm{S}_{\mathrm{L}}=\mathrm{PI}_{\mathrm{L}} / \mathrm{TPI}$ indicates the ratio of the amount of net premiums written in a particular line of business $\left(\mathrm{PI}_{\mathrm{L}}\right)$ over the total amount of net premiums written in all lines (TPI). Additionally, following Sommer (1996) and Pottier and Sommer (1999), we include the proportion of net premiums derived from long-tail liability business as another control variable. The rationale is that firms with a higher proportion of long-tail business may exhibit a higher underwriting risk. If insurers trade off underwriting risk and investment risk, an insurer with a higher index of business-line concentration and a larger percentage of long-tail liability business is more likely to pursue a conservative investment strategy.

Organizational form: The insurance industry is characterized by the diversity of organizational forms - shareholder-owned stock insurers, and policyholder-owned mutual insurers (Adams, 1999). In their well-known managerial discretion hypothesis, Mayers and Smith $(1981,1994)$ argue that by integrating the owner-policyholder functions, mutuals are more efficient than their stock counterparts in controlling shareholder-policyholder agency conflicts, but are less effective in controlling owner-manager incentive conflicts. Therefore, they predict that mutual P-L insurers will be mainly pronounced in simple and less diverse business lines and less geographical areas in order to limit managerial discretion. Indeed, Lamm-Tennant and 
Starks (1993) find that stock insurers tend to have a higher level of underwriting risk than do mutuals. Additionally, Cummins and Sommer (1996) argue that the risk-taking of a firm should be inversely related to the degree of separation of ownership from management. This is because the more separation of ownership from management, the greater misalignment between the interests of managers and owners. As a result, such managers might be more concerned about their own job security and so engage in less risk taking. ${ }^{10}$ Moreover, Zou, Yang, Wang and Zhu (2008) provide evidence supporting that mutual insurers are more likely to face capital constraints and suffer from agency costs of equity, thereby adopting a more conservative dividend policy than stock insurers do. Compared with stock insurers, mutuals tend to have a higher degree of separation of ownership and management and therefore they are more likely to have a lower underwriting and/or investment risk than do stock firms (e.g., see Baranoff and Sager, 2002). We therefore include a dummy variable (1 for a stock insurer) in our model and expect it to have a positive sign in the models of underwriting and investment risks.

Group status: Whether an insurer is an independent firm or a member of a group is likely to be important when firm managers choose the levels of underwriting and investment risks. Intuitively, affiliated insurers are exposed to less capital constraints because of the possible funding help from other associated firms within the group and therefore may afford to bear more risks (i.e., having a larger risk capacity) (Cummins and Sommer, 1996). Consistent with this argument, Colquitt et al. (1999) find that an affiliated P-L firm generally holds less cash than an independent firm. A dummy variable with value 1 indicating a group-affiliated firm is included and a positive sign is expected in the models of underwriting and investment risks.

\footnotetext{
${ }^{10}$ This is because, unlike shareholders, company managers are often inefficient in diversifying their personal wealth outside the company (Mayers and Smith, 1981).
} 
Franchise value: Franchise value, sometimes referred to as intangible assets (e.g., name, reputation, agency force in place, licensing agreements), is particularly important to financial institutions including insurers (Pottier and Sommer, 1999). Keeley (1990), Demestz et al. (1996) and Saunders and Wilson (2001) contend that a bank's existing franchise value provides managers disincentives for excessive risk-taking. Consistent with this view, Staking and Babbel (1995) report a negative relationship between an insurer's interest rate risk exposure and its franchise value. Following Pottier and Sommer (1999), we use A.M. Best's financial strength rating to measure an insurer's franchise value. ${ }^{11}$ Our numeric coding defines a lower value of rating as better financial strength and a higher franchise value and such firms are expected to engage in less risk-taking. In other words, we expect the rating variable to have a positive sign in the risk models. On the other hand, as rating can represent the financial strength of insurers, it is likely that there is a positive relationship between the rating measure and an insurer's underwriting and investment risks. In order to mitigate the potential endogeneity between underwriting/investment risk and rating, we use an insurer's rating in the previous year in the analysis.

Regulation: $\quad$ Prior studies (e.g., Cummins and Sommer, 1996; Sommer, 1996) report that New York state has a more stringent licensing and solvency regulation than do other states. Therefore, other things being equal, it is possible that insurers operating in New York may have a lower level of overall risk tolerance than insurers operating outside New York State. This factor may also have an effect on insurers' underwriting and investment risks though the

\footnotetext{
${ }^{11}$ Specifically, we define franchise value $(\mathrm{FV})=1$ if the Best rating is $\mathrm{A}++$ or $\mathrm{A}+; \mathrm{FV}=2$ if the rating is $\mathrm{A}$ or $\mathrm{A}-$; $\mathrm{FV}=3$ if the rating is $\mathrm{B}++$ or $\mathrm{B}+$; $\mathrm{FV}=4$ if the rating is $\mathrm{B}$ or $\mathrm{B}-; \mathrm{FV}=5$ if the rating is $\mathrm{C}++$ or $\mathrm{C}+$; and $\mathrm{FV}=6$ if the rating is $\mathrm{C}, \mathrm{C}-$, or $\mathrm{D}$. We also exclude the insurers without rating (codes 88 or 99 ) or with rating under the regulatory supervision, or in liquidation, or with rating suspended.
} 
direction of such influence is not known as a priori. We include the proportion of gross premium written from New York State to control for such a possibility.

Distribution channel: Cummins and Sommer (1996) argue that insurers relying on independent agents to sell policies can take on a higher risk because such agents have little human capital specific to a particular insurer. We therefore include a dummy variable that takes one for independent agents and zero otherwise.

Volatility of financial markets: The volatility of financial markets may affect insurers' investment strategy and increase their investment risk. In addition to investing in bonds and stocks, insurance companies may also use financial derivatives (Cummins et al., 2001; De Ceuster, Flanagan, Hodgson, and Tahir, 2003). If insurers trade off investment risk against underwriting risk, the volatility of financial market may also potentially affect underwriting risk. Following Cummins and Sommer (1996), we include the annual volatility change in bond and S\&P 500 index return in the models to capture the effects of market volatility.

Operating scope: Finally, we control for the effects of operating scope by including a dummy variable with value one indicating national insurers and zero otherwise. Operating scope may affect an insurer's underwriting risk (e.g., through geographical and business-line diversification) and may potentially affect its investment risk if an insurer makes joint decisions the two core risks.

We also include year dummies in models to control for time-related factors (e.g., underwriting cycles, the occurrence of catastrophes, etc.).

\section{Data}


Our original dataset is from the regulatory annual statements filed by P-L insurers with the National Association of Insurance Commissioners (NAIC) for the period 1993 through 2000to us, while our analysis is for the sample period 1994 to $2000 .^{12}$ Starting from 1994 is necessary as the risk-based capital (RBC) system was implemented in that year, which may cause structural changes in insurers' capital and risk-taking decisions. The terrorist attacks on September 11, 2001 caused U.S. insurers to pay billions of dollars in damages and induced significant rate hikes following the attack and as a result, the event has the potential to change the relation between investment risk and underwriting risk. It would be interesting to examine whether this is indeed the case. However, this examination is not possible in the current study because we do not have access to data beyond 2001. The focus on the relation between investment risk and underwriting risk before 2001 is a limitation of our study, and we leave the impact of this catastrophic loss event as a topic of future research. Nevertheless, we feel that the results from our study can be usefully compared against future research using more updated data.

In common with prior studies (e.g., Sommer, 1996; Cummins, Phillips and Smith, 2001), a firm to be included in the sample needs to satisfy the following criteria: a) with consistently positive asset and surplus values over the 1993-2000 period; b) with positive net premium written between 1993 and 2000; c) being either a stock or a mutual firm during the sample period in order to avoid the confounding effects of organizational changes on risk taking behavior; d) with available information for the variables used in the analysis. Reciprocals and Lloyds

\footnotetext{
${ }^{12}$ The inclusion of year 1993 data is to extract the lag values in some variables.
} 
Syndicates are excluded as they are deemed to be outside the scope of the current study. Our selection criteria result in a final sample of 581 firms and 3,523 year-firm observations. ${ }^{13}$

\section{Results}

\subsection{Descriptive and univariate results}

Table 1 provides the definition of each variable included in the analysis and Table 2 presents the descriptive statistics for the dependent and independent variables. Where necessary, variables are winsorized at the $1 \%$ level at the left and/or right tail to eliminate the effects of extreme values. The mean combined ratio of our sample firms is at an average value of $105 \%$ suggesting an unfavorable underwriting performance and this may motivate P-L insurers to further enhance their overall return via investment. The mean value of investment risk is 0.208 suggesting that our sample firms on average invest about $21 \%$ of their investable assets in common stocks. The alternative measure of investment risk is defined as the percentage of investment in common stocks, preferred stocks and long-term low-grade bonds (with a maturity over five years). The ratio of this risky asset allocation is about $42 \%$. The sample firms have an operation history about 69 years and have a mean capital ratio of $42 \%$. In addition, $63 \%$ of the sample firms are stock insurers and $78 \%$ of the sample firms are affiliated to a group. In terms of the underwriting activities, the sample firms underwrite a significant proportion of long-tail lines of businesses, which contributes about $67 \%$ to the total net premium. ${ }^{14}$ Moreover, about $80 \%$ of insurers rely on independent agencies as the distribution channel and about $17 \%$ of insurers operate nationally. These statistics are similar to those reported in Cummins and Sommer (1996).

\footnotetext{
${ }^{13}$ The panel data is unbalanced and Stata - the statistical software that we use - can conveniently handle the related estimation issue of unbalanced panel datasets internally.

${ }^{14}$ Among the total 35 underwritten insurance lines, 13 of them are long-tail insurance and have generated significant amount of premium income.
} 
We also calculate a correlation coefficient between underwriting and investment risks and the computed Pearson correlation coefficient (unreported for brevity) is not statistically significant. Therefore, the univariate analysis provides no evidence supporting that insurers trade off one core risk against the other.

[Insert Table $1 \& 2$ here]

\subsection{Multivariate results}

To capture the interactions between $U R$ and $I R$ for P-L insurers, we estimate a system of simultaneous equations (Equations (8) and (9)) and follow the standard methodology to examine the model identification. Following the order condition rule, in both equations, the number of (endogenous and exogenous) variables missing from each equation is equal to 1 (the total number of endogenous variables 2 minus 1) (see Kennedy, 1998, p.171). Therefore, each equation and hence the system is exactly identified. Prior studies (e.g., Cummins and Sommer, 1996; Baranoff and Sager, 2002) document that autocorrelated error terms are common in the specification of insurers' risk profile. This is an issue since our sample is a panel dataset. We therefore estimate the system of simultaneous equations using the two-stage least square (2SLS) procedure with heteroskedasticity robust standard errors clustered at the firm level to allow for within-firm autocorrelation. In the first stage, the endogenous variables ( $U R$ and $I R$ ) are instrumented by their respective lagged values and the control variables used in the system.

\subsubsection{Basic results}


Table 3 summarizes the results based on simultaneous equations model. The control variable of financial market volatility is measured by either volatility change in S\&P index or volatility change in bond return. ${ }^{15}$ In particular, Columns [1] and [2] of Table 3 report the results of the model including the volatility change in S\&P index as a proxy for financial market volatility, whereas Columns [3] and [4] demonstrate the results of the model including the volatility change in bond return as a proxy. The results are similar in the two sets of analysis and our discussions focus on Columns [1] and [2].

\section{[Insert Table 3 here]}

Consistent with the co-movement hypothesis (H2), IR and $U R$ are positively correlated, but insignificant at the $10 \%$ level). Therefore, there is no significant evidence in support of the co-movement hypothesis nor the trade-off hypothesis. Instead, it seems that insurers do not consider underwriting risk and investment risk as a joint decision.

As expected, the coefficients of lagged $U R$ and lagged $I R$ are found to be positive and significant at the $1 \%$ level in the model of $U R$ and $I R$, respectively. The coefficient value 0.554 of the lagged $U R$ in the $I R$ equation suggests that the partial adjustment speed, defined as 1-the coefficient of lagged $U R$, is about $44.6 \%$. In addition, the partial adjustment speed of $I R$ is $4.8 \%$. The results suggest that on average it takes insurers about two years to adjust to their target level of underwriting risk, where it takes a longer time period to adjust to the target level of investment risk. The latter result is surprising as the cost of adjusting investment portfolio in theory should be lower than adjusting the underwriting portfolio. Nevertheless, using a large sample for the period 1996-2008, Chen, Sun, Yao and Yu (2010) also find that P-L insurers are slower in

\footnotetext{
${ }^{15}$ If we include them simultaneously in the models, none of their coefficient estimate is statistically significant (these two variables have a correlation coefficient of 0.52 ).
} 
adjusting investment risk measured by the duration of the bond portfolio held by an insurer (they report an adjustment speed of $24 \%$ ). While a detailed study of this phenomenon is beyond the scope of the current study, we conjecture that the inconsistency between expectation and empirical evidence can be due to the short-term feature of P-L insurance contracts. P-L insurance contracts are often valid for one year and renewable afterwards and this provides insurers an opportunity to adjust their underwriting risk within one or two years. In addition, compared to other investment vehicles, investment in common stock is more risky. Thus, if an insurer adopts a long-term investment strategy with a carefully chosen stock portfolio and uses the fund from a stable source (e.g., retained earnings) in such risky investment, a low adjustment speed in investment risk is possible.

Among the control variables, the results suggest that insurers with a poor financial strength rating and/or with more long-tail business tend to have a higher underwriting risk than other firms. The result on financial strength rating confirms that insurers with good financial strength rating tend to take less underwriting risk in order to protect their franchise value. In addition, insurers that are large, have a higher capital ratio or less business written in New York tend to invest more of their assets in risky common stocks. The finding on capital ratio implies that insurers with a high level of capital adequacy opt to bear more investment risks, which is consistent with that of Cummins and Sommer (1996). The coefficient of the stock dummy is unexpectedly negative and significant in the model of $I R$, suggesting that mutual insurers tend to adopt a more aggressive investment strategy. Volatility change in S\&P index is found to have a positive effect on investment risk, whereas a negative effect on underwriting risk. In Columns [3] 
and [4], we replace volatility change in S\&P index with volatility change in bond return and find similar results.

Table 3 also reports two diagnostic checks on the validity of instruments for $U R$ and $I R$. The $F$-tests of the excluded instrument (lagged $U R$ for $U R$ and lagged $I R$ for $I R$ ) are always highly significant ( $p$-values lower than 0.01 ). More illustrative than these standard $F$-tests are Shea's (1997) partial $\mathrm{R}^{2}$ that all well exceed the suggested ("rule of thumb") hurdle of $10 \%$. Therefore, the instruments are valid and there is no weak identification problem. ${ }^{16}$

\subsubsection{Underwriting-investment-risk relation and risk capacity}

As discussed in Section 2, the relation between insurers' underwriting and investment risks may vary according to insurers' overall risk capacity. For example, when an insurer's overall risk is low and has extra risk capacity, it may simultaneously increase both risks; in contrast, if an insurer's risk is approaching the regulatory limit, it may choose to trade off one risk against the other. In order to test for this possibility, we partition our sample into two subsamples according to whether the value of Kenney ratio is over 2 or not. Kenney ratio, defined as the ratio of net premiums written to capital, has been traditionally viewed as a key underwriting capacity and insolvency ratio (as net premiums written are a rough proxy of future liabilities). As a rule of thumb, it is generally believed that the Kenney ratio of an insurer should not exceed 2 in order to keep insolvency risk in check. The regression results are reported in Table 4.

[Insert Table 4 here]

\footnotetext{
${ }^{16}$ We cannot use Sargan/Hansen test to examine whether the instrument is correlated with the error term of the model since our system of simultaneous equations is exactly identified. 
First, the results reported under the Columns "Kenney Ratio $\geq 2$ " show that $U R$ is negatively related to $I R$ among insurers that have little extra risk capacity, albeit the coefficient of IR is insignificant. The coefficient estimate of $U R$ is positive and insignificant in the $I R$ model. We then turn to the results from using the subsample with a Kenney ratio<2 (reported in Columns [3] and [4]). The coefficient of $I R(U R)$ is positive but significant in the $U R(I R)$ model, These results suggest that regardless of the risk capacity, insurers do not seem to consider underwriting and investment risks jointly and so we find support for neither the co-movement nor the trade-off hypothesis. In the rest of models, we replace volatility change in S\&P index with volatility change in bond return, and find similar results.

\subsection{Robustness checks}

In this section, we conduct several robustness checks to examine the sensitivity of our results. First, we estimate the system of simultaneous equations in three alternative ways: (1) 2SLS estimation with Newey-West standard errors that are robust to unknown heteroskedasticity and autocorrelation; (2) 2SLS estimation incorporating random-effects; and (3) the fullinformation three-stage least square (3SLS). ${ }^{17}$ The regression results on $U R$ and $I R$ are tabulated under Panels A, B and C of Table 5. It is apparent that the tenor of our results is robust with these alternative estimations - i.e., there is no significant evidence suggesting insurers consider underwriting and investment risk jointly. In addition, the robustness check of the subsample analysis based on risk capacity is also conducted and does provide robust results.

\section{[Insert Table 5 here]}

\footnotetext{
${ }^{17}$ Fixed-effects cannot be incorporated given that the stock dummy is time-invariant.
} 
The following robustness test is based on the use of alternative measure for investment risk. Pottier and Sommer (1999) find that investment risk, measured by the proportion of junk bonds and common stocks scaled by the invested assets, is negatively related to firm rating. They suggest that an increased ratio of junk bonds and common stocks in invested assets represents a more risky investment portfolio. In this part, we use an alternative measure of investment risk (IR2) that includes the proportion of investments in common stocks, preferred stocks, and longterm low-grade bonds (refer to Table 1 for detailed definition). We include investments in preferred stocks because such investments should be more risky than bond investments. As shown in Table 2, the mean proportion of investment in these risky assets is about $42 \%$. Using this alternative measure for IR, we then repeat all the analyses summarized in Sections 5.2.1 and 5.2.2. In unreported results, neither the coefficient of $I R$ in the $U R$ model nor the effect of $U R$ in the $I R$ model is found to be statistically significant in the pooled and split sample analysis.

\section{Conclusion}

Underwriting and investment are the two important business activities in the insurance industry. While the extant literature has investigated the relation between insurers' overall risk and capital level (Cummins and Sommer, 1996), the difference in underwriting risk between stock and mutual insurers (Lamm-Tennant and Starks, 1993), and the asset risk, product risk and capital in the U.S. life insurers (Baranoff and Sager, 2002), there is little research examining the interrelation between underwriting and investment risks of P-L insurers. Our study attempts to investigate the linkage between the underwriting and investment risks in the P-L insurance industry for the sample period 1994-2000 under a simultaneous equations framework. Especially, 
we intend to examine whether insurers jointly determine the level of their underwriting and investment risks prior to the 9-11 event.

We posit two non-mutually exclusive arguments the co-movement and trade-off hypothesis. Measuring underwriting risk as the combined ratio and investment risk as the proportion of investments in common stocks, we find no significant support for either of the arguments. Our result is thus different from the finding that insurers tend to trade off underwriting (investment) risk against investment (underwriting) risk reported in Hammond et al. (1976). Our results, nevertheless, provide some support for Achleitner et al.'s (2002) conjecture that the insurance industry may have overlooked the correlation between underwriting and investment risks and largely managed investment in isolation from underwriting. This silo approach can then lead to the assumption of excessive risk relating to the same source (e.g., aviation industry risk) by many P-L insurers.

Our paper serves as the first systematic investigation of the interrelation between P-L insurers' underwriting and investment risks. Future studies should benefit from using a sample period post 9-11 event and examining the effect of September 11 terrorist attack on the interrelation between insurers' underwriting and investment risks. In particular, it is of interest to see whether insurers adopt an integrated approach to considering their overall risks so that the catastrophe losses from multiple exposures can be mitigated after the 9-11 event. In the aftermath of the recent global financial crisis, risk taking and risk management of financial institutions have received more attention and increasing scrutiny. We believe the current paper provides some useful insights in this vein. 


\section{Reference}

Achleitner, P.M., Biebel, J.H., Wichels, D., 2002. Does WTC matter for the investment policy of p/c insurance companies? Geneva Papers on Risk and Insurance: Issues and Practices 27, 275282.

Adams, M., 1999. Determinants of participatory rights insurance: evidence from the New Zealand life insurance industry. Applied Financial Economics 9, 483-490.

Adams, M., Buckle, M.J., 2003, The determinants of corporate financial performance in the Bermuda insurance market. Applied Financial Economics 23, 133-143.

Baranoff, E.G., Sager, T.W., 2002. The relationship among asset risk, product risk, and capital in the life insurance industry. Journal of Banking and Finance 26, 1181-1197.

Boose, M.A., 1993. Investment returns of life insurers: tests of agency theory and its alternatives. Managerial Finance 19, 18-34.

Chen, C.R., Steiner, T.L., White, A.M., 2001. Risk taking behavior and managerial ownership in the United States life insurance industry. Applied Financial Economics 11, 165-171.

Chen, X.J., Sun, Z.Z., Yao, T., Yu, T., 2010. Preferred habitat: Insights from insurers' treasury bond portfolios, Working Paper, University of Rhode Island.

Colquitt, L.L., Sommer, D.W., Godwin, N.H., 1999. Determinants of cash holdings by propertyliability Insurers. Journal of Risk and Insurance 66, 401-415.

Cummins, J.D., Doherty, N.A., 2002. Capitalization of the property-liability insurance industry: Overview. Journal of Financial Services Research 21, 5-14.

Cummins, D.J., Sommer, D.W., 1996. Capital and risk in property-liability insurance markets. Journal of Banking and Finance 20, 1069-1092.

Cummins, J. D., Phillips, R. D., Smith, S. D., 2001. Derivatives and corporate risk management: participation and volume decisions in the insurance industry. Journal of Risk and Insurance 68, 51-92.

Demsetz, R., Saidenberg, M., Strahan, P., 1996. Banks with something to lose: the disciplinary role of franchise value. FRBNY Economic Policy Review October, 1-14.

Downs, D.H., Sommer, D.W., 1999. Monitoring, ownership, and risk-taking: the impact of guaranty funds. Journal of Risk and Insurance 66, 477-497.

Fairley, W.B., 1979. Investment income and profit margins in property-liability insurance: theory and empirical results. Bell Journal of Economics 10, 192-207.

Hammond, J.D., Melander, E.R., Shilling, N., 1976. Risk, return, and the capital market: the insurer case. Journal of Financial and Quantitative Analysis 11, 115-131.

Hammond, J.D., Shilling, N., 1978. Some relationships of portfolio theory to the regulation of insurer solidity. Journal of Risk and Insurance 45, 377-400. 
Hardwick, P., 1997. Measuring cost inefficiency in the UK life insurance industry. Applied Financial Economics 7, 37-44.

Harrington, S.E., Nelson, J., 1986. A regression-based methodology for solvency surveillance in the property-liability insurance industry. Journal of Risk and Insurance 53, 583-605.

Harrington, S.E., Niehaus, G., 2002. Capital structure decisions in the insurance industry: stocks versus mutuals. Journal of Financial Services Research 21, 145-163.

Hoyt, R.E., Trieschmann, J.S., 1991. Risk/return relationships for life-health, property-liability, and diversified insurers. Journal of Risk and Insurance 58, 322-330.

Keeley, M.C., 1990. Deposit insurance, risk, and market power in banking. American Economic Review 80, 1183-1196.

Kennedy, P., 1998. A Guide to Econometrics. Blackwell, Oxford.

Lamm-Tennant, J., Starks, L., 1993. Stock versus mutual ownership structures: the risk implications. Journal of Business 66, 29-46.

Lee, C.F., Forbes, S.W., 1982. Income measures, ownership, capacity ratios and the dividend decision of the non-life insurance industry: some empirical evidence. Journal of Risk and Insurance 49, 269-289.

Lee, A.C., Cummins, J.D., 1998. Alternative models for estimating the cost of equity capital for property/casualty insurers. Review of Quantitative Finance \& Accounting 10, 235-267.

De Ceuster, M., Flanagan, M., Hodgson, A., Tahir, M.I., 2003. Determinants of derivative usage in the life and general insurance industry: The Australian evidence. Review of Pacific Basin Financial Markets and Policies 6, 405-431.

Mayers, D., Smith, C.W. 1981. Contractual provisions, organizational structures, and conflict control in insurance. Journal of Business 54, 407-434.

Mayers, D., Smith, C.W., 1994. Managerial discretion, regulation, and stock insurer ownership structure. Journal of Risk and Insurance 61, 638-655.

Moridaira, S., Urrutia, J.L., Witt, R.C., 1992. The equilibrium insurance price and underwriting return in a capital market setting. Journal of Risk and Insurance 59, 291-300.

Pottier, S.W., Sommer, D.W., 1999. Property-liability insurer financial strength ratings: differences across rating agencies. Journal of Risk and Insurance 66, 621-642.

Saunders, A., Strock, F., Travlos, N., 1990. Ownership structure, deregulation, and bank risk taking. Journal of Finance 45, 643-654. 
Saunders, A., Wilson, B., 2001. An analysis of bank charter value and its risk-constraining incentives. Journal of Financial Services Research 19, 185-195.

Shea, J. 1997. Instrument relevance in multivariate linear models: A simple measure. Review of Economics and Statistics 49, 348-352.

Smith, B.D., 2001. A financial analysis of the property and casualty insurance industry 19701999. CPCU Journal 54, 134-148.

Smith, C.W., Watts, R.L., 1992. The investment opportunity set and corporate financing, dividend, and compensation policies. Journal of Financial Economics 32, 263-292.

Sommer, D.W., 1996. The impact of firm risk on property-liability insurance prices. Journal of Risk and Insurance 63, 501-514.

Staking, K.B., Babbel, D.F., 1995. The relation between capital structure, interest rate sensitivity, and market value in the property-liability insurance industry. Journal of Risk and Insurance 62, 690-718.

Wei, K.C. J., 1988. An asset-pricing theory unifying the CAPM and APT. Journal of Finance 43,881-892.

Zou, H., Yang, C., Wang, M., Zhu, M., 2008. Dividend decisions in the property and liability insurance industry: mutual versus stock companies. Review of Quantitative Finance \& Accounting 33, 113-139. 
Table 1: Variable definitions

\begin{tabular}{|c|c|c|}
\hline & Variables & Definition \\
\hline 1 & Underwriting risk (UR) & $\begin{array}{l}\text { Measured by an insurer's loss ratio plus expense ratio (including } \\
\text { underwriting expenses), i.e., the combined ratio. Winsorized at } 1 \% \\
\text { on both tails. }\end{array}$ \\
\hline 2 & Investment risk (IR) & $\begin{array}{l}\text { The proportion of investment in common stock, measured as } \\
\text { common stock holdings divided by an insurer's cash and other } \\
\text { investable funds. Winsorized at the top } 1 \% \text {. }\end{array}$ \\
\hline 3 & Investment risk 2 (IR2) & $\begin{array}{l}\text { The proportion of investment in common stock, preferred stock, and } \\
\text { long-term low-grade bonds (i.e., class- } 3 \text { to class- } 6 \text { bonds with a } \\
\text { maturity over } 5 \text { years). Winsorized at } 1 \% \text { on both tails. }\end{array}$ \\
\hline 4 & Firm size & Measured by logarithm of total (admitted) assets \\
\hline 5 & Firm age & Measured by the number of operation years since inception \\
\hline 6 & Lagged capital ratio & $\begin{array}{l}\text { Measured as the ratio of total capital (surplus) to total book value of } \\
\text { assets, lagged by one year }\end{array}$ \\
\hline 7 & Stock firm dummy & 1 for stock insurers and 0 for mutual insurers \\
\hline 8 & Group dummy & 1 for firms affiliated to a group \\
\hline 9 & Lagged rating & $\begin{array}{l}\text { Proxy for franchise value and financial strength, measured by the } \\
\text { A.M. Best rating, with low values for good ratings }\end{array}$ \\
\hline 10 & Business-line mix & $\begin{array}{l}\text { Computed as the sum of the squared fraction of net premium written } \\
\text { in each of } 26 \text { lines of insurance and used to measure the } \\
\text { concentration of insurance lines }\end{array}$ \\
\hline 11 & Business from New York & $\begin{array}{l}\text { The ratio of net premium written in New York State to total net } \\
\text { premium }\end{array}$ \\
\hline 12 & Long-tail business & $\begin{array}{l}\text { The proportion of premiums from long-tail business to total net } \\
\text { premium }\end{array}$ \\
\hline 13 & $\begin{array}{l}\text { Independent agency } \\
\text { dummy }\end{array}$ & $\begin{array}{l}1 \text { if an insurer relies on independent agencies to sell policies and } 0 \text { if } \\
\text { otherwise }\end{array}$ \\
\hline 14 & $\begin{array}{l}\text { Volatility change in S\&P } \\
\text { index }\end{array}$ & $\begin{array}{l}\text { Annualized standard deviation of monthly return for } S \& P 500 \text { index } \\
\text { in year } t \div \text { annualized standard deviation of monthly return for } S \& P \\
500 \text { index in year } t-1\end{array}$ \\
\hline 15 & $\begin{array}{l}\text { Volatility change in bond } \\
\text { return }\end{array}$ & $\begin{array}{l}\text { Annualized standard deviation of monthly return for two-year US } \\
\text { Treasury-bills in year } t \div \text { annualized standard deviation of monthly } \\
\text { return for two-year US Treasury-bills in year } t-1\end{array}$ \\
\hline 16 & National insurer dummy & 1 for a national insurer and 0 for otherwise. \\
\hline
\end{tabular}


Table 2: Descriptive statistics ( $\mathrm{N}=3523)$

\begin{tabular}{lrrrrr}
\hline Variables & \multicolumn{1}{c}{ Mean } & \multicolumn{1}{c}{ Median } & \multicolumn{1}{c}{ Std. Dev } & \multicolumn{1}{c}{ Min } & \multicolumn{1}{c}{ Max } \\
\hline Underwriting risk (UR) & 1.050 & 1.036 & 0.190 & 0.116 & 2.603 \\
Investment risk (IR) & 0.208 & 0.162 & 0.176 & 0.000 & 0.841 \\
Investment risk 2 (IR2) & 0.415 & 0.348 & 0.291 & 0.000 & 0.980 \\
Firm size & 18.832 & 18.749 & 1.836 & 13.480 & 24.379 \\
Firm age & 69.058 & 57.000 & 43.956 & 12.000 & 209.000 \\
Lagged capital ratio & 0.419 & 0.374 & 0.182 & 0.080 & 0.989 \\
Stock firm dummy & 0.632 & 1.000 & 0.482 & 0.000 & 1.000 \\
Group dummy & 0.775 & 1.000 & 0.418 & 0.000 & 1.000 \\
Lagged rating & 2.886 & 2.000 & 8.797 & 1.000 & 99.000 \\
Business-line mix & 0.407 & 0.321 & 0.246 & 0.091 & 1.000 \\
Business from New York & 0.079 & 0.000 & 0.203 & -0.126 & 1.002 \\
Long-tail business & 0.670 & 0.729 & 0.260 & 0.000 & 1.000 \\
Independent agency dummy & 0.793 & 1.000 & 0.406 & 0.000 & 1.000 \\
Volatility change in S\&P index & 1.310 & 1.349 & 0.555 & 0.483 & 2.113 \\
Volatility change in bond return & 1.002 & 1.045 & 0.150 & 0.768 & 1.213 \\
National insurer dummy & 0.173 & 0.000 & 0.378 & 0.000 & 1.000 \\
\hline
\end{tabular}


Table 3: Multivariate results of simultaneous equation models

\begin{tabular}{|c|c|c|c|c|}
\hline \multirow[t]{2}{*}{ Dependent variable } & UR & IR & UR & IR \\
\hline & {$[1]$} & [2] & {$[3]$} & {$[4]$} \\
\hline \multirow[t]{2}{*}{ Investment risk (IR) } & 0.009 & & 0.009 & \\
\hline & {$[0.312]$} & & {$[0.330]$} & \\
\hline \multirow[t]{2}{*}{ Lagged investment risk } & & $0.952 * * *$ & & $0.952 * * *$ \\
\hline & & {$[92.344]$} & & {$[92.506]$} \\
\hline \multirow[t]{2}{*}{ Underwriting risk (UR) } & & 0.010 & & 0.011 \\
\hline & & {$[1.004]$} & & [1.059] \\
\hline \multirow[t]{2}{*}{ Lagged underwriting risk } & $0.554 * * *$ & & $0.554 * * *$ & \\
\hline & {$[12.004]$} & & [11.964] & \\
\hline \multirow[t]{2}{*}{ Firm size } & 0.001 & $0.003 * * *$ & 0.001 & $0.003^{* * *}$ \\
\hline & {$[0.165]$} & {$[3.272]$} & {$[0.203]$} & {$[3.231]$} \\
\hline \multirow[t]{2}{*}{ Firm age } & 0.001 & 0.001 & 0.001 & 0.001 \\
\hline & {$[0.844]$} & {$[-0.151]$} & [0.863] & {$[-0.175]$} \\
\hline \multirow[t]{2}{*}{ Lagged capital ratio } & -0.031 & $0.037 * * *$ & -0.030 & $0.036^{* * *}$ \\
\hline & {$[-0.866]$} & {$[4.020]$} & {$[-0.835]$} & [3.981] \\
\hline \multirow{2}{*}{ Stock firm dummy } & 0.004 & $-0.004 *$ & 0.004 & $-0.004 *$ \\
\hline & {$[0.517]$} & {$[-1.721]$} & [0.513] & {$[-1.714]$} \\
\hline \multirow[t]{2}{*}{ Group dummy } & -0.015 & 0.002 & -0.015 & 0.002 \\
\hline & {$[-1.455]$} & [0.697] & {$[-1.464]$} & {$[0.715]$} \\
\hline \multirow[t]{2}{*}{ Lagged rating } & $0.001 * *$ & 0.001 & $0.001 * *$ & 0.001 \\
\hline & {$[2.134]$} & {$[1.008]$} & {$[2.176]$} & [0.898] \\
\hline \multirow[t]{2}{*}{ Business-line mix } & -0.023 & 0.002 & -0.023 & 0.002 \\
\hline & {$[-1.492]$} & {$[0.512]$} & {$[-1.504]$} & [0.527] \\
\hline \multirow[t]{2}{*}{ Business from New York } & -0.007 & $-0.012 * * *$ & -0.007 & $-0.012 * * *$ \\
\hline & {$[-0.499]$} & {$[-3.189]$} & {$[-0.490]$} & {$[-3.188]$} \\
\hline \multirow[t]{2}{*}{ Long-tail business } & $0.052 * * *$ & 0.007 & $0.052 * * *$ & 0.007 \\
\hline & {$[3.342]$} & [1.637] & {$[3.341]$} & {$[1.637]$} \\
\hline \multirow[t]{2}{*}{ Independent agency dummy } & 0.009 & 0.001 & 0.008 & 0.001 \\
\hline & [1.057] & {$[-0.151]$} & [1.049] & {$[-0.136]$} \\
\hline \multirow[t]{2}{*}{ Volatility change in S\&P index } & $-0.014 * *$ & $0.006^{* * *}$ & & \\
\hline & {$[-2.131]$} & {$[2.641]$} & & \\
\hline \multirow[t]{2}{*}{ Volatility change in bond return } & & & -0.044 & $0.022 * * *$ \\
\hline & & & {$[-1.543]$} & {$[2.667]$} \\
\hline \multirow[t]{2}{*}{ National insurer dummy } & 0.008 & 0.001 & 0.008 & 0.001 \\
\hline & {$[1.206]$} & [0.204] & [1.242] & {$[0.167]$} \\
\hline Year dummies & yes & yes & yes & yes \\
\hline F-test of the excluded IV (p-value) & 0.000 & 0.000 & 0.000 & 0.000 \\
\hline Shea's (1997) partial $\mathrm{R}^{2}$ & 0.848 & 0.289 & 0.847 & 0.286 \\
\hline Adjusted $\mathrm{R}^{2}$ & 0.334 & 0.905 & 0.334 & 0.905 \\
\hline
\end{tabular}


This table reports the regression results of simultaneous equations. Columns [1] and [2] is the simultaneous system using Volatility change in S\&P index to measure financial market volatility and Columns [3] and [4] is the system using Volatility change in bond return to measure market volatility. Reported in brackets are t-values computed using heteroskedasticity robust standard errors clustered at the firm level to allow for within-firm autocorrelation. ***, **, * denotes significance at the 1,5, and 10 percent levels, respectively (two-tailed). The F-test of the excluded instrument variable and the Shea's (1997) all suggest the excluded instrument variable of the underwriting and investment risk is relevant and rule out the possibility of weak identification. All models include a constant and its coefficient estimates are omitted for brevity. 
Table 4: Multivariate results of simultaneous equation models - split sample analysis

\begin{tabular}{|c|c|c|c|c|c|c|c|c|}
\hline \multirow{3}{*}{ Dependent variable } & \multicolumn{2}{|c|}{ Kenney ratio $>=2$} & \multicolumn{2}{|c|}{ Kenney ratio $<2$} & \multicolumn{2}{|c|}{ Kenney ratio $>=2$} & \multicolumn{2}{|c|}{ Kenney ratio $<2$} \\
\hline & UR & IR & UR & IR & UR & IR & UR & IR \\
\hline & {$[1]$} & {$[2]$} & {$[3]$} & {$[4]$} & {$[5]$} & {$[6]$} & [7] & [8] \\
\hline \multirow[t]{2}{*}{ Investment risk (IR) } & -0.068 & & 0.015 & & -0.063 & & 0.015 & \\
\hline & {$[-1.502]$} & & {$[0.500]$} & & {$[-1.393]$} & & {$[0.509]$} & \\
\hline \multirow[t]{2}{*}{ Lagged investment risk } & & $0.896 * * *$ & & $0.955 * * *$ & & $0.896^{* * *}$ & & $0.955 * * *$ \\
\hline & & {$[18.813]$} & & {$[91.571]$} & & {$[18.902]$} & & {$[91.652]$} \\
\hline Underwriting risk (UR) & & {$[0.276]$} & & {$[0.979]$} & & {$[0.330]$} & & {$[1.022]$} \\
\hline \multirow[t]{2}{*}{ Lagged underwriting risk } & $0.574 * * *$ & & $0.552 * * *$ & & $0.571 * * *$ & & $0.552 * * *$ & \\
\hline & [9.808] & & {$[11.480]$} & & {$[9.681]$} & & {$[11.448]$} & \\
\hline \multirow[t]{2}{*}{ Firm size } & 0.001 & 0.002 & 0.001 & $0.002 * * *$ & 0.001 & 0.002 & 0.001 & $0.002 * * *$ \\
\hline & {$[0.368]$} & {$[1.269]$} & {$[0.118]$} & {$[2.704]$} & {$[0.325]$} & {$[1.288]$} & {$[0.150]$} & {$[2.666]$} \\
\hline \multirow[t]{2}{*}{ Firm age } & 0.001 & 0.001 & 0.001 & 0.001 & 0.001 & 0.001 & 0.001 & 0.001 \\
\hline & {$[0.536]$} & {$[-0.480]$} & {$[0.747]$} & {$[-0.049]$} & {$[0.618]$} & {$[-0.519]$} & {$[0.756]$} & {$[-0.061]$} \\
\hline Lagged capital ratio & {$[0.058]$} & {$[1.141]$} & {$[-0.867]$} & {$[3.248]$} & {$[0.071]$} & {$[1.183]$} & {$[-0.842]$} & {$[3.205]$} \\
\hline \multirow[t]{2}{*}{ Stock firm dummy } & 0.009 & 0.007 & 0.005 & $-0.005^{* *}$ & 0.009 & 0.007 & 0.005 & $-0.005^{* *}$ \\
\hline & {$[0.676]$} & {$[0.872]$} & {$[0.470]$} & {$[-1.999]$} & {$[0.645]$} & {$[0.871]$} & {$[0.465]$} & {$[-1.987]$} \\
\hline \multirow[t]{2}{*}{ Group dummy } & 0.001 & -0.006 & -0.019 & 0.003 & -0.001 & -0.005 & -0.019 & 0.002 \\
\hline & {$[0.025]$} & {$[-0.722]$} & {$[-1.552]$} & {$[0.946]$} & {$[-0.062]$} & {$[-0.690]$} & {$[-1.545]$} & {$[0.934]$} \\
\hline \multirow[t]{2}{*}{ Lagged rating } & $0.001 *$ & 0.001 & $0.001 *$ & 0.001 & $0.001 *$ & 0.001 & $0.001 *$ & 0.001 \\
\hline & [1.699] & {$[-0.354]$} & {$[1.890]$} & [1.106] & [1.821] & {$[-0.413]$} & [1.923] & [1.016] \\
\hline \multirow[t]{2}{*}{ Business-line mix } & -0.037 & -0.020 & -0.023 & 0.004 & -0.035 & -0.020 & -0.023 & 0.004 \\
\hline & {$[-1.457]$} & {$[-1.318]$} & {$[-1.368]$} & {$[0.841]$} & {$[-1.369]$} & {$[-1.344]$} & {$[-1.390]$} & {$[0.869]$} \\
\hline \multirow[t]{2}{*}{ Business from New York } & -0.025 & $-0.021 * * *$ & -0.003 & $-0.013 * * *$ & -0.025 & $-0.021 * * *$ & -0.003 & $-0.013 * * *$ \\
\hline & {$[-1.108]$} & {$[-2.774]$} & {$[-0.153]$} & {$[-2.764]$} & {$[-1.090]$} & {$[-2.786]$} & {$[-0.148]$} & {$[-2.764]$} \\
\hline
\end{tabular}


0.024

Independent agency dummy

[0.812]

$0.030 * * *$

$0.056 * * *$

0.003

0.024

$0.030^{* *}$

$0.055^{* * *}$

0.003

0.020

[2.599]

[3.153]

[0.706]

[0.837]

[2.559]

[3.149]

[0.715]

Volatility change in S\&P index

[1.501]

$-0.005$

0.020

$-0.005$

0.006

$-0.018$

0.004

$-0.014^{*}$

[1.561]

[-0.501]

[0.707]

[0.260]

Volatility change in bond return

[-1.907]

[2.445]

National insurer dummy

Year dummies

F-test of the excluded IV (p-value)

(1.430

[0.555]

Shea's (1997) partial $\mathrm{R}^{2}$

Adjusted R ${ }^{2}$

$\begin{array}{ccc}-0.001 & 0.005 & 0.009 \\ {[-0.086]} & {[0.484]} & {[1.249]} \\ \text { yes } & \text { yes } & \text { yes } \\ 0.000 & 0.000 & 0.000 \\ 0.748 & 0.305 & 0.853 \\ 0.386 & 0.779 & 0.331 \\ 468 & 468 & 3055\end{array}$

0.001

$-0.076$

0.026

$-0.041$

$0.022 * *$

[-1.323]

[0.726]

[-1.333]

[2.558]

0.001

0.001

0.009

0.001

[-0.055]

[0.033]

[0.470]

[1.266]

$[-0.073]$

yes

yes

yes

yes

yes

0.000
0.284

0.000
0.750

0.000

0.000

0.000

0.908

0.387

0.300

0.853

0.284

3055

468

0.779

0.331

0.908

This table reports the regression results of simultaneous equations for firm-years with Kenney ratio above or below 2. Reported in brackets are t-values computed using heteroskedasticity robust standard errors clustered at the firm level to allow for within-firm autocorrelation. $* * * * * *$ denotes significance at the 1,5 , and 10 percent level, respectively (two-tailed). The F-test of the excluded instrument variable and the Shea's (1997) all suggest the excluded instrument variable of the underwriting and investment risk is relevant and rule out the possibility of weak identification. All models include a constant and its coefficient estimates are omitted for brevity. 
Table 5: Robustness checks: summary of results from alternative estimations of the simultaneous equation models

Panel A: Newey-West estimator that is robust to unknown heteroskedasticity and autocorrelation

\begin{tabular}{lcccccc}
\hline \multirow{3}{*}{ Dependent variable } & \multicolumn{2}{c}{ Pooled } & \multicolumn{2}{c}{ Kenney Ratio $>=2$} & \multicolumn{2}{c}{ Kenney Ratio $<2$} \\
\cline { 2 - 7 } & UR & IR & UR & IR & UR & IR \\
\cline { 2 - 7 } & {$[1]$} & {$[2]$} & {$[3]$} & {$[4]$} & {$[5]$} & {$[6]$} \\
\hline Investment risk (IR) & 0.009 & & -0.068 & & 0.015 & \\
& {$[0.424]$} & & {$[-1.458]$} & & {$[0.668]$} & \\
Underwriting risk (UR) & & 0.010 & & 0.014 & & 0.010 \\
& & {$[1.110]$} & & {$[0.348]$} & & {$[1.063]$} \\
\hline
\end{tabular}

Bandwidth of 3 is used in estimation

Panel B: instrument variable using random-effects panel model

\begin{tabular}{lcccccc}
\hline \multirow{3}{*}{ Dependent variable } & \multicolumn{2}{c}{ Pooled } & \multicolumn{2}{c}{ Kenney Ratio $>=2$} & \multicolumn{2}{c}{ Kenney Ratio <2 } \\
\cline { 2 - 7 } & UR & IR & UR & IR & UR & IR \\
\cline { 2 - 7 } & {$[1]$} & {$[2]$} & {$[3]$} & {$[4]$} & {$[5]$} & {$[6]$} \\
\hline Investment risk (IR) & 0.009 & & -0.047 & & 0.015 & \\
& {$[0.420]$} & & {$[-0.704]$} & & {$[0.661]$} & \\
Underwriting risk (UR) & & 0.010 & & 0.026 & & 0.011 \\
& & {$[1.040]$} & & {$[0.453]$} & & {$[1.010]$} \\
\hline
\end{tabular}

$\underline{\text { Panel C: three-stage least square estimation }}$

\begin{tabular}{lcccccc}
\hline \multirow{3}{*}{ Dependent variable } & \multicolumn{2}{c}{ Pooled } & \multicolumn{2}{c}{ Kenney Ratio $>=2$} & \multicolumn{2}{c}{ Kenney Ratio $<2$} \\
\cline { 2 - 7 } & UR & IR & UR & IR & UR & IR \\
\cline { 2 - 7 } & {$[1]$} & {$[2]$} & {$[3]$} & {$[4]$} & {$[5]$} & {$[6]$} \\
\hline Investment risk (IR) & 0.009 & & -0.068 & & 0.014 & \\
& {$[0.420]$} & & {$[-1.470]$} & & {$[0.660]$} & \\
Underwriting risk (UR) & & 0.010 & & 0.014 & & 0.010 \\
& & {$[1.120]$} & & {$[0.350]$} & & {$[0.280]$} \\
\hline
\end{tabular}

This table reports the regression results of alternative estimations of the simultaneous equations. Results are based on models controlling for the volatility change in S\&P 500 index return. 